Baseline

\title{
Trace element concentrations in the apex predator swordfish (Xiphias gladius) from a Mediterranean fishery and risk assessment for consumers
}

\author{
S. Gobert ${ }^{\mathrm{a}}$, V. Pasqualini ${ }^{\mathrm{b}, \mathrm{c}}$, J. Dijoux ${ }^{\mathrm{b}}$, P. Lejeune ${ }^{\mathrm{d}}$, E.D.H. Durieux ${ }^{\mathrm{b}, \mathrm{c}}$, M. Marengo $^{\mathrm{a}, \mathrm{b}, *}$

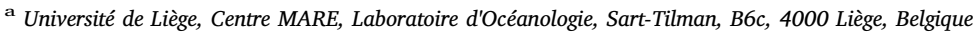 \\ b Université de Corse Pascal Paoli, UMR 6134 CNRS-UCPP Sciences pour l'Environnement, 20250 Corte, France \\ c Université de Corse Pascal Paoli, UMS 3514 CNRS-UCPP Plateforme marine Stella Mare, 20620 Biguglia, France \\ d Station de Recherche Sous-marines et Océanographiques (STARESO), 20260 Calvi, France
}

\section{A R T I C L E I N F O}

\section{Keywords:}

Contamination

Trace elements

Fisheries

Human health

\begin{abstract}
A B S T R A C T
Swordfish (Xiphias gladius L., 1758) is an apex predator, highly migratory meso-pelagic fish widely distributed in the Atlantic Ocean and Mediterranean. As top predators, this fish may be the end reservoir of the bioaccumulation of trace elements in a food chain because they occupy higher trophic levels and are an important food source, causing them to be potentially hazardous to consume. This study aims to investigate the concentration of 18 trace elements of Swordfish, caught in the Mediterranean Sea and to discuss human exposure risks. The mean element levels in the fish muscles were clearly below the maximum allowable concentrations established by International food safety regulations. The data suggested that the risk is minor and acceptable for human health. The findings of this study amplify the scarce database on contaminants available, especially new data on "emerging elements", for this species from the Mediterranean Sea.
\end{abstract}

Trace elements (TE) are natural trace components of the marine environment, but their levels have increased due to domestic, industrial, mining and agricultural activities (Bakan and Büyükgüngör, 2000). TE are generally classified as essential (e.g. copper, zinc, iron, manganese), probably essential (e.g. nickel, vanadium, cobalt) and potentially toxic (e.g. arsenic, cadmium, lead, mercury) (Muñoz-Olivas and Cámara, 2001). At low levels, some TE are essential for enzymatic activity and many biological processes (Bat et al., 2012). The main roles of these essential elements can be described as functional (a catalyzing role) and structural (integrators of the organic compounds) (Mendil et al., 2010). TE become toxic when their intake is excessive or when ingested over a long time period and even potentially carcinogenic to humans (Uluozlu et al., 2007). TE can be bioaccumulated by marine organisms through a variety of pathways, including respiration, adsorption and ingestion (Türkmen et al., 2008). These elements can be biomagnified via the food chain and finally be assimilated by human marine food consumers involving health risks (Baeyens et al., 2005). The presence of trace element from anthropogenic origin in marine ecosystems has been a serious problem for the environment and human health (Araújo and Cedeño-Macias, 2016). Their intake can lead to adverse health effects like renal dysfunction, lung disease, liver failure, dysfunctions in the kidneys, chronic damage to the central and peripheral nervous system (Dadar et al., 2016). TE pollution of the sea is less visible and direct than other types of marine pollution (e.g. Macro-waste) but its effects on marine ecosystems and humans are intense and very extensive (Erkan et al., 2009). Among the wide range of toxic substances contaminating the marine environment, a major concern has been focused on specific trace element (Castro-González and Méndez-Armenta, 2008).

Fish represents a powerful model for risk-benefit assessment (Di Bella et al., 2015). In the last years, the health benefits related with seafood consumption have been extensively publicized (Mendil et al., 2010). The world consumption of fish has increased simultaneously with the growing concern of their nutritional and therapeutic benefits (El-Moselhy et al., 2014). In addition to its important source of protein, fish typically have rich contents of essential minerals, vitamins and unsaturated fatty acids (Medeiros et al., 2012). However, the content of toxic TE in fish can counteract their beneficial effects (Castro-González and Méndez-Armenta, 2008). As recently pointed out, high concentrations of these elements are found in the Mediterranean Sea in many types of commercially important fish (Demirak et al., 2006; Kalay et al., 1999; Papetti and Rossi, 2009a).

Swordfish (Xiphias gladius L., 1758) is an apex predator, highly migratory meso-pelagic fish widely distributed in the Atlantic Ocean and Mediterranean (Macías et al., 2005). It is a large species of high commercial value, reaching a maximum length of $445 \mathrm{~cm}$, weighing up

\footnotetext{
* Corresponding author at: Université de Liège, Centre MARE, Laboratoire d'Océanologie, Sart-Tilman, B6c, 4000 Liège, Belgique.

E-mail address: marengo@univ-corse.fr (M. Marengo).
} 
to $540 \mathrm{~kg}$ and it can live for 25 years (Nakamura, 1985). Swordfish are opportunistic predators that feed primarily on pelagic fishes and invertebrates, particularly squid (Hernández-García, 1995). Swordfish typically forage in deep water during the day and stay in the mixed layer at night (Abascal et al., 2010). Based on stomach contents from $X$. gladius, it is most likely true that the swordfish uses its sword to kill some of its prey, as is shown by the slashes on the bodies of prey found in swordfish stomachs (B. Collette et al., 2016). Genetic studies suggest that all Mediterranean swordfish form a unique stock that is reproductively isolated from the Atlantic stock, indicating little genetic exchange occurring between the two (Kotoulas et al., 1995). Life history differences (e.g. growth and sexual maturity) have been noted between Mediterranean and Atlantic swordfish (Macías et al., 2005). In the Mediterranean a large, socio-economically important fishery targets this species (Aliçli and Oray, 2001), reported catch for 2015 was to 9.966 t (Aliçli and Oray, 2001; Neves dos Santos et al., 2016). Swordfish is a much sought-after table fish and consumer demand is increasing. The Mediterranean population of Swordfish was therefore regionally assessed as Near Threatened (NT) in an overview of the conservation status of Mediterranean fishes (Malak, 2011). This stock is not considered to be well-managed. In addition, the majority of the catch includes juveniles (below $90 \mathrm{~cm}$ Lower Jaw-Fork Length). This pauperization of Mediterranean swordfish population is due to a number of reasons, including overfishing and pollution (Damiano et al., 2011). Quota have now been instaured for 2017 onwards in order to protect this overharvested population. The limit was set at $10,500 \mathrm{t}$ for 2017 at a meeting of the International Commission for the Conservation of Atlantic Tunas (ICCAT) in Vilamoura, Portugal. It will be lowered by $3 \%$ per year from 2018 to 2022 .

Studies of anthropogenic contaminants in large, long-lived predatory fish such as swordfish are important for several reasons. As top predators, this fish may be the end reservoir of the bioaccumulation of trace elements in a food chain because they occupy higher trophic levels and are an important food source, causing them to be potentially hazardous to consume (Mansour and Sidky, 2002). Trace elements accumulation in fish is dependent on numerous factors, and the accumulation pattern is the result of physiological uptake and elimination rates (Guven et al., 1999). Absorption of these elements may occur directly from the water, through the gills, but the main route seems to be the gastrointestinal absorption of those elements present in food (Olsson et al., 1998). Furthermore, because these species are apex predators, they carry out very intense metabolic activities that require a continuous supply of energy (Kojadinovic et al., 2007). As a result, their rate of predation and food consumption is extremely high, a property which contributes notably to the accumulation of pollutants (M.M. Storelli et al., 2005). As a consequence, TE concentration in the muscle of top predatory organisms, will reflect the environment in which they live (Szefer et al., 2003). Thus, fish tissues such as swordfish can be used as biomonitors for levels of TE compounds in the Mediterranean Sea.

As a result, the present study aims (i) to determine the levels of ten essential or probably essential metal elements ( $\mathrm{Co}, \mathrm{Cr}, \mathrm{Cu}, \mathrm{Fe}, \mathrm{Mn}, \mathrm{Mo}$, $\mathrm{Ni}, \mathrm{Se}, \mathrm{V}$ and $\mathrm{Zi}$ ) and the eight non-essential ones (Ag, $\mathrm{Al}, \mathrm{Be}, \mathrm{Bi}, \mathrm{Cd}, \mathrm{Pb}$, $\mathrm{Sb}, \mathrm{Sn}$ ) in the muscle of swordfish caught in the Mediterranean Sea, (ii) to compare the relationships between elements concentrations and the correlations existing among them (iii) to estimate the weekly intake of these trace metals, comparing them with the Provisional Tolerable Weekly Intake (PTWI) (iv) to discuss human exposure risks with regards to International food safety regulations.

Thirty-three specimens of swordfish were obtained by fishing vessels from two sites (Bastia, Saint-Florent, Est and West coast, respectively) around Corsica Island (Mediterranean Sea) between December 2011 and August 2012. Samples and data were carefully collected by fishermen and scientific observers. Fishing location, length measurement to the nearest $\mathrm{cm}$ (Total Length - TL) and weight $(\mathrm{kg})$ were recorded for each fish. A sample of around $10 \mathrm{~g}$ (wet weight, ww)
Table 1

Some morphometric and biological characteristics (mean \pm SD) of mediterranean swordfish, values in parentheses indicate minimum-maximum values.

\begin{tabular}{llll}
\hline $\begin{array}{l}\text { Number of } \\
\text { individual }\end{array}$ & Total length $(\mathrm{cm})$ & $\begin{array}{l}\text { Body weight range } \\
(\mathrm{kg})\end{array}$ & $\begin{array}{l}\text { Data collection } \\
\text { (years) }\end{array}$ \\
\hline $\begin{array}{c}33\left(23 \sigma^{\prime}, 10\right. \\
\text { Q })\end{array}$ & $114 \pm 31(70-160)$ & $18 \pm 7(4-30)$ & $2011-2012$ \\
\hline
\end{tabular}

was then taken from the dorsal white muscle. The tissues were frozen at $-20{ }^{\circ} \mathrm{C}$ until analysis in the laboratory. The biological data of the specimens are shown in Table 1.

Before the analysis, samples were thawed and cleaned with ultrapure water. Samples were mineralized in Teflon digestion vessels, in a closed microwave digestion labstation (Ethos D, Milestone Inc.), using nitric acid and hydrogen peroxide as reagents (suprapur grade, Merck). Analyses of 18 trace elements (Be, Al, V, Mn, Co, As, Se, Mo, Ag, Sn, Sb, $\mathrm{Bi}, \mathrm{Cr}, \mathrm{Fe}, \mathrm{Ni}, \mathrm{Cu}, \mathrm{Pb}, \mathrm{Cd}$ ) were determined by Inductively Coupled Plasma Mass Spectrometry using Dynamic Reaction Cell technology (ICP-MS ELAN DRC II, PerkinElmer ${ }^{\circledR}$ ).

In order to check the purity of the chemicals used, a number of chemical blanks were run; there was no evidence of any contamination in these blanks. Analytical quality control was achieved using Certified Reference Materials (CRM), DOLT-3: dogfish liver, NIST 1566b: oyster tissue, NIST 1577c: bovine liver and NIST 2976: mussel tissue. The results obtained on the Certified Reference Materials showing good agreement with the certified values for all TE (global mean recovery was $92 \pm 16 \%$ ), noticing that for $\mathrm{Be}$ and $\mathrm{Bi}$ no certified values were reported. For each TE, detection decision (LC), detection limit (LD) and quantification limit (LQ) were calculated, depending on their specific blank distribution (Currie, 1999). The results are expressed in milligrams of element per kilogram of body weight wet ( $\mathrm{mg} \mathrm{kg}^{-1} \mathrm{ww}$ ).

All data were checked, beforehand, for goodness of fit to a normal distribution with Kolmogorov-Smirnov's test and homogeneity of variance using a Bartlett test. To better meet the assumptions of standard parametric statistical tests, to reduce the effect of outliers on skewing the data distribution and to bring elemental concentrations within the same range, the data were natural-log transformed. TE concentrations that were found to be below their analytical LD were considered as half of the LD value during data statistical treatment.

Multivariate analysis of variance (MANOVA) was used to test the effect of localities (Bastia/Saint-Florent), and sex (Male/Female) on eighteen element traces concentrations. Pearson rank correlations test were used to investigate the relationship between the trace metal levels between them (inter-elementary correlations) as well as the relationship with the biological data (weight). The correlation coefficient (r) was calculated together with $p$-values to determine the significance and strength of each correlation. A p value of $<0.05$ was considered to indicate statistical significance.

Risk of TE intake on a weekly basis was estimated by calculating the respective levels found in $X$. gladius, for a person weighing $70 \mathrm{~kg}$ and with a weekly consumption rate of $427 \mathrm{~g}$ (defined for European population) (FAO, 2016). The Estimated Weekly Intake (EWI, $\mathrm{mg} \mathrm{kg}{ }^{-1}$ ), was determined using the following equation:

$E W I=\left(C_{m} * I R_{w}\right) / B W$

$C_{m}$ represents the TE concentration in fish $\left(\mathrm{mg} \mathrm{kg}^{-1}\right), I R_{w}$ the weekly ingestion rate $(\mathrm{kg})$ and $B W$ the body weight $(\mathrm{kg})$. To assess the public health risks, these weekly intake were compared with the Provisional Tolerable Weekly Intake (PTWI), recommended by the Joint FAO/WHO Expert Committee on Food Additives (JECFA). This index shows appropriate safe exposure levels and is used to estimate the amount of contaminants, ingested over a lifetime without appreciable risk (Chamannejadian et al., 2013). The European Food Safety Autority (EFSA) has established regulatory guidelines, the PTWI of $\mathrm{Cd}$ and $\mathrm{Pb}$ 
Table 2

Mean ( \pm standard deviation; SD) and range of trace elements concentrations ( $\mathrm{mg} \mathrm{kg}^{-1} \mathrm{ww}$ ) in the muscle of mediterranean swordfish caught in Corsica.

\begin{tabular}{llll}
\hline Element & Mean $( \pm \mathrm{SD})$ & Min & Max \\
\hline $\mathrm{Ag}$ & $0.005( \pm 0.001)$ & 0,000 & 0,023 \\
$\mathrm{Al}$ & $0.943( \pm 0.089)$ & 0,311 & 2527 \\
$\mathrm{Be}$ & $0.023( \pm 0.003)$ & 0,000 & 0,070 \\
$\mathrm{Bi}$ & $0.000( \pm 0.000)$ & 0,000 & 0,002 \\
$\mathrm{Cd}$ & $0.033( \pm 0.009)$ & 0,003 & 0,290 \\
$\mathrm{Co}$ & $0.008( \pm 0.003)$ & 0,001 & 0,060 \\
$\mathrm{Cr}$ & 0,003 & 0,542 \\
$\mathrm{Cu}$ & $0.043( \pm 0.020)$ & 0,122 & 0,769 \\
$\mathrm{Fe}$ & $0.349( \pm 0.029)$ & 1340 & 18,406 \\
$\mathrm{Mn}$ & $4.808( \pm 0.706)$ & 0,018 & 0,374 \\
$\mathrm{Mo}$ & $0.072( \pm 0.014)$ & 0,001 & 0,094 \\
$\mathrm{Ni}$ & $0.009( \pm 0.003)$ & 0,001 & 3191 \\
$\mathrm{~Pb}$ & $0.271( \pm 0.124)$ & 0,001 & 2196 \\
$\mathrm{Sb}$ & $0.084( \pm 0.066)$ & 0,181 & 0,024 \\
$\mathrm{Se}$ & $0.008( \pm 0.001)$ & 0,000 & 2513 \\
$\mathrm{Sn}$ & $0.552( \pm 0.072)$ & 0,000 & 0,026 \\
$\mathrm{~V}$ & $0.003( \pm 0.001)$ & 4120 & 0,017 \\
$\mathrm{Zn}$ & $0.003( \pm 0.001)$ & & 331,015 \\
\hline
\end{tabular}

was 7 and $25 \mu \mathrm{gg}^{-1}$ week $^{-1}$, respectively. Therefore, PTWI of Cd and $\mathrm{Pb}$ for a $70 \mathrm{~kg}$ person is 490 and $1750 \mu \mathrm{g}$ week $^{-1}$, respectively. Furthermore, a selection of essential group of TE (Cr, $\mathrm{Cu}, \mathrm{Fe}, \mathrm{Ni}, \mathrm{Zn}$ ) and their PTWI values were calculated and compared.

Trace elements concentrations (mean, standard deviation, minimum and maximum) in the muscle tissues of swordfish are shown in Table 2. The mean concentrations of trace elements are quite variable (Fig. 1) such as, $\mathrm{Zn}(121.101 \pm 218.967), \mathrm{Al}(3.770 \pm 2.056)$ or $\mathrm{Cr}$ $(0.172 \pm 0.449)$. Distribution patterns in concentration of TE follows the sequence: $\mathrm{Zn}>\mathrm{Fe}>\mathrm{Al}>\mathrm{Se}>\mathrm{Cu}>\mathrm{Ni}>\mathrm{Pb}>\mathrm{Mn}>$ $\mathrm{Cr}>\mathrm{Cd}>\mathrm{Be}>\mathrm{Mo}>\mathrm{Co} \mathrm{Sb}>\mathrm{Ag}>\mathrm{Sn}>\mathrm{V}>\mathrm{Bi}$. Thus, among the trace elements analyzed, $\mathrm{Zn}$ showed the highest concentration. In contrast, concentrations of $\mathrm{Bi}, \mathrm{V}, \mathrm{Sn}$ or $\mathrm{Ag}$ were low. Be levels
Table 3

MANOVA results for testing the effects of location and sex on trace element concentrations in muscle of Mediterranean swordfish caught in Corsica. $f$-values and $p$-values of the tests used (*p $\left.<0.05 ;{ }^{* *} \mathrm{p}<0.01 ; * * * \mathrm{p}<0.001\right)$.

\begin{tabular}{lllll}
\hline Factor & Location & \multicolumn{3}{l}{ Sex } \\
\hline Trace element concentrations & $F$ & $P$ & $F$ & $P$ \\
& 2.671 & 0.284 & 2.670 & 0.278 \\
\hline
\end{tabular}

were low in all individuals with a certain number of values under the detection limit of the ICP-MS. European legislation (E.U, 2008) established maximum levels for $\mathrm{Pb}$ and $\mathrm{Cd}$, with values set at $0.3 \mathrm{mg} \mathrm{kg}^{-1}$. For $\mathrm{Pb}$ and $\mathrm{Cd}$ the average concentrations $\left(0.083 \mathrm{mg} \mathrm{kg}^{-1}\right.$ and $0.033 \mathrm{mg} \mathrm{kg}^{-1}$, respectively) observed in this study were lower than the maximum of the food safety regulations established by WHO and European Community. For $\mathrm{Pb}$ in most of the fish samples, values were below the guideline level (32/33 individuals) and only one tested samples exceeded this limit (Max: $2.195 \mathrm{mg} \mathrm{kg}^{-1}$ ).

MANOVA results indicated that there were no significant differences in accumulation patterns of trace element between the two study areas (localities) and the males and females (sex) (Table 3).

The relationship between the fish weight and the trace element concentrations and also inter-relationship between elements in the muscles of the swordfish were investigated and shown in Table 4.

There was a significantly positive correlation between the weight of the fish and the concentrations of three trace element $(\mathrm{Pb}: \mathrm{r}=0.35$, $\mathrm{p}<0.05 ; \mathrm{V}: \mathrm{r}=0.35, \mathrm{p}<0.05 ; \mathrm{Zn}: \mathrm{r}=0.60, \mathrm{p}<0.001)$. For others trace elements, no significant correlations were detected between concentrations and weight of individuals.

Trace elements found in muscles also showed strong and moderate correlations with one another in some cases (see Table 4).

The PTWI values recommended by the expert committee on food additives, joint FAO/WHO Expert Committee on Food Additives (WHO, 2014) were used to compare the estimated weekly intakes of trace

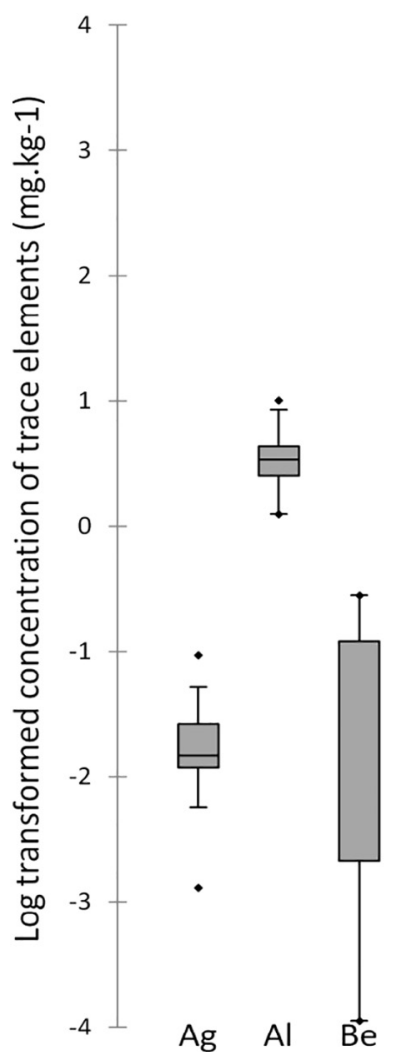

$\mathrm{Ag} \quad \mathrm{Al} \quad \mathrm{Be} \quad \mathrm{Bi} \quad \mathrm{Cd} \quad \mathrm{Co} \quad \mathrm{Cr} \quad \mathrm{Cu}$
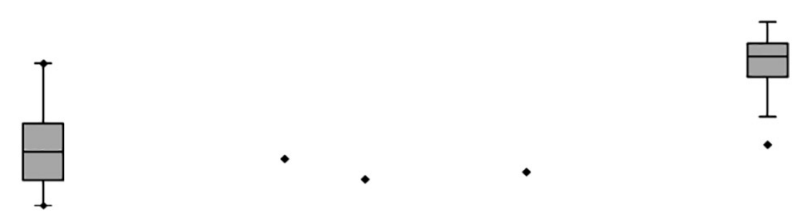

Fig. 1. Boxplot of the 18 trace elements in the muscle of mediterranean swordfish caught in Corsica 
Table 4

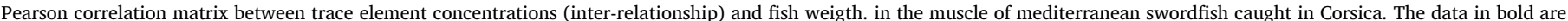
statistically significant.

\begin{tabular}{|c|c|c|c|c|c|c|c|c|c|c|c|c|c|c|c|c|c|c|}
\hline Element & Weight & $\mathrm{Ag}$ & $\mathrm{Al}$ & $\mathrm{Be}$ & $\mathrm{Bi}$ & $\mathrm{Cd}$ & Co & $\mathrm{Cr}$ & $\mathrm{Cu}$ & $\mathrm{Fe}$ & Mn & Mo & $\mathrm{Ni}$ & $\mathrm{Pb}$ & $\mathrm{Sb}$ & $\mathrm{Se}$ & Sn & $\mathrm{V}$ \\
\hline $\mathrm{Ag}$ & 0.29 & & & & & & & & & & & & & & & & & \\
\hline $\mathrm{Al}$ & 0.21 & 0.02 & & & & & & & & & & & & & & & & \\
\hline $\mathrm{Be}$ & 0.02 & 0.23 & 0.27 & & & & & & & & & & & & & & & \\
\hline $\mathrm{Bi}$ & 0.14 & 0.15 & $0.45^{* *}$ & -0.21 & & & & & & & & & & & & & & \\
\hline $\mathrm{Cd}$ & 0.09 & 0.38 & 0.09 & 0.21 & -0.11 & & & & & & & & & & & & & \\
\hline Co & 0.25 & -0.01 & 0.25 & -0.13 & $0.51^{* *}$ & -0.09 & & & & & & & & & & & & \\
\hline $\mathrm{Cr}$ & 0.19 & -0.18 & 0.15 & $-0.37^{*}$ & $0.48^{* *}$ & -0.16 & $0.73^{* * * *}$ & & & & & & & & & & & \\
\hline $\mathrm{Cu}$ & 0.04 & -0.03 & 0.09 & -0.23 & 0.34 & -0.05 & $0.63^{* * * *}$ & $0.52^{* *}$ & & & & & & & & & & \\
\hline $\mathrm{Fe}$ & 0.20 & -0.16 & 0.01 & -0.32 & $0.36^{*}$ & -0.09 & $0.56^{* * * *}$ & $0.65^{* * *}$ & $0.74^{* * * * *}$ & & & & & & & & & \\
\hline $\mathrm{Mn}$ & 0.15 & -0.14 & 0.13 & -0.33 & $0.55^{* * * *}$ & -0.29 & $0.82^{* * * *}$ & $0.82^{* * *}$ & $0.80^{* * * * *}$ & $0.71^{* * * *}$ & & & & & & & & \\
\hline Mo & 0.27 & 0.17 & 0.13 & -0.23 & $0.48^{* * * *}$ & -0.08 & $0.80^{* * * * *}$ & $0.80^{* * *}$ & $0.55^{* * * *}$ & $0.62^{* * * * *}$ & $0.78^{* * * *}$ & & & & & & & \\
\hline $\mathrm{Ni}$ & 0.26 & 0.13 & 0.18 & -0.07 & $0.51^{* * * *}$ & 0.01 & $0.85^{* * * *}$ & $0.75^{* * *}$ & $0.47^{* * * *}$ & $0.47^{* * * *}$ & $0.76^{* * * *}$ & $0.89^{* * *}$ & & & & & & \\
\hline $\mathrm{Pb}$ & 0.35 & -0.07 & $0.48^{* *}$ & -0.14 & $0.62^{* * * *}$ & -0.25 & $0.46^{* * * *}$ & $0.49^{* * * *}$ & 0.27 & $0.41^{* * * *}$ & $0.54^{* * * *}$ & 0.44 & 0.52 & & & & & \\
\hline $\mathrm{Sb}$ & 0.16 & $0.83^{* * *}$ & 0.16 & $0.37^{*}$ & 0.31 & 0.34 & 0.04 & -0.14 & -0.05 & -0.22 & -0.12 & 0.17 & 0.21 & -0.02 & & & & \\
\hline $\mathrm{Se}$ & 0.14 & -0.06 & 0.12 & -0.13 & 0.26 & -0.07 & 0.33 & 0.27 & $0.56^{* * * *}$ & $0.78^{* * * *}$ & $0.40^{*}$ & 0.34 & 0.17 & 0.23 & -0.11 & & & \\
\hline Sn & 0.03 & -0.42 & 0.35 & -0.25 & 0.23 & -0.24 & -0.05 & 0.20 & 0.10 & 0.28 & 0.08 & 0.01 & -0.14 & 0.32 & -0.33 & 0.30 & & \\
\hline $\mathrm{V}$ & 0.35 & 0.03 & 0.30 & -0.05 & $0.37 *$ & -0.07 & $0.69^{* * *}$ & $0.64^{* * * *}$ & $0.57^{* * * *}$ & $0.57^{* * * *}$ & $0.63^{* * *}$ & $0.60^{* * * *}$ & 0.51 & $0.46^{* * * *}$ & 0.12 & $0.41^{*}$ & 0.14 & \\
\hline $\mathrm{Zn}$ & $0.60^{* * * *}$ & 0.10 & 0.25 & -0.15 & 0.33 & -0.02 & $0.42^{*}$ & 0.29 & $0.57^{* * * * *}$ & $0.58^{* * * *}$ & $0.45^{* * *}$ & 0.34 & 0.29 & $0.47^{* * *}$ & 0.04 & $0.59^{* * * *}$ & 0.26 & $0.51^{* * * *}$ \\
\hline
\end{tabular}

$* \mathrm{p}<0.05$.

*** $\mathrm{p}<0.01$.

**** $\mathrm{p}<0.001$

Table 5

The estimated weekly intakes for swordfish.

\begin{tabular}{llll}
\hline Metal & PTWI $^{\mathrm{a}}$ & PTWI $^{\mathrm{b}}$ & EWI \\
\hline $\mathrm{Cd}$ & 7 & 490 & 0.203 \\
$\mathrm{Cr}$ & 637 & 44,590 & 0.262 \\
$\mathrm{Cu}$ & 3500 & 245,000 & 2.129 \\
$\mathrm{Fe}$ & 5600 & 392,000 & 29.32 \\
$\mathrm{Ni}$ & 35 & 2450 & 1.651 \\
$\mathrm{~Pb}$ & 25 & 1750 & 0.511 \\
$\mathrm{Zn}$ & 7000 & 490,000 & 184.679 \\
\hline
\end{tabular}

${ }^{\text {a }}$ Provisional Permissible Tolerable Weekly Intake (PTWI) in $\mu \mathrm{g} /$ week $/ \mathrm{kg}$ body weight.

${ }^{\mathrm{b}}$ PTWI for $70 \mathrm{~kg}$ adult person in $\mu \mathrm{g} / \mathrm{week} / 70 \mathrm{~kg}$ body weight. EWI. Estimated Weekly intakes in $\mu \mathrm{g} / \mathrm{week} / 70 \mathrm{~kg}$ body weight.

elements in this study. The result from Table 5 suggests that the EWI of $\mathrm{Cd}, \mathrm{Cr}, \mathrm{Cu} \mathrm{Fe}, \mathrm{Ni}, \mathrm{Pb}$ and $\mathrm{Zn}$ by a $70 \mathrm{~kg}$ adult consuming $427 \mathrm{~g}$ of swordfish/week were all below the limit set by European regulation.

The levels of TE in swordfish were determined and assessed by comparing levels found in samples with permissible limits stipulated by various organizations. Compared to existing international food safety regulations and literature data, our results contribute to the identification of risks for mediterranean population associated with fish consumption. The European Union has established regulatory guidelines regarding dietary cadmium and lead concentrations $\left(0.3 \mathrm{mg} \mathrm{kg}^{-1} \mathrm{ww}\right)$. Cadmium accumulates in human body and may induce kidney dysfunction, skeletal damage, and reproductive deficiencies (Tuzen and Soylak, 2007). Impairment of hearing ability, anemia, renal failure, weakened immune system and premature births, are the most common symptoms of lead poisoning (Yildirim et al., 2009). The mean element levels in the fish muscles observed in this study were clearly below the maximum allowable concentrations established by WHO and European Community in food. Considering those limits, only one swordfish was reported to exceed $\mathrm{Pb}$ values, and all fish appeared safe for consumption regarding $\mathrm{Cd}$ exposure. The data modalities considered in this study suggested that the risk is minor and acceptable for human health. However, it should be taken into account that Mercury $(\mathrm{Hg})$ was not measured in this study. Mercury has received much attention due to the well-known toxic effects of this metal (Storelli and Marcotrigiano, 2001). Potential dietary exposure of $\mathrm{Hg}$ continues to be a subject of research, regulation and debate (Storelli et al., 2007). Given its capacity for biomagnification along food webs, mercury is often present at high levels in marine species. Several authors (Damiano et al., 2011; Papetti and Rossi, 2009b; Pastor et al., 1994; M.M. Storelli et al., 2005; Storelli and Marcotrigiano, 2001) reported moderate to high levels of mercury in swordfish caught in the Mediterrenean Sea. Swordfish, usually accumulates mercury as methyl mercury, while inorganic mercury usually represents a minor proportion of the total mercury present in the tissues (Vlieg et al., 1993). Methyl mercury does not occur naturally in water, and its presence in fish muscle is due to in vivo biochemical transformation or by ingestion of preformed methyl mercury along the food chain (Mendez et al., 2001). Consequently, a large percentage of $\mathrm{Hg}$ is present as toxic $\mathrm{MeHg}$ in the edible portions of fish consumed by man (Kojadinovic et al., 2007b). From a public health point of view, the consumption of fish with high mercury content does not represent a hazard, provided that it is not eaten on a regular basis (Mendez et al., 2001). Despite the fact that our results do not show high concentrations of TE and associated risks, it remains important that higher concentrations could be found in particularly large and elderly individuals due to bioaccumulation on certain elements.

Concerning the estimation of the potential public health risks, the PTWI values were used to compare the estimated dietary intakes of trace elements in this study. The estimated weekly intake for cadmium and lead were far below the established PTWI values, it may be concluded that consumption of this species is not a problem on human health. Furthermore, the estimated intakes of chrome, copper, iron, nickel, and zinc from weekly consumption of swordfish are lower than the respective established PTWI for these elements and data modalities considered in this study.

This permissible limits should be considered as a suggested value and not an absolute one that provides a margin of safety (Onsanit et al., 2012). The regular consumption of fish is important and increasing, due to the nutritional values linked to fatty acids, some vitamins, minerals and protein, and can make a positive contribution to the prevention of cardiovascular disease and the development of the fotus (Di Bella et al., 2015). The analyzed swordfish samples represent a good nutritional source of essential trace elements. Thus, combining the detection of contaminants concentrations in food and the estimated consumption limits is of great relevance in view of assessing the balance between benefits and risks (Copat et al., 2013).

There have been very few studies on trace elements in swordfish in the Mediterranean Sea and around the world. But it should be noted that fish size, trophic position, diet and the geographical areas (both 
biotic and abiotic factors) may have variable effects on the bioaccumulation of trace elements in swordfish populations. Hence caution is needed in data interpretation comparing with previous studies around the world. The comparison of our results with published data showed lower levels of lead $\left(0.084 \mathrm{mg} \mathrm{kg}^{-1}\right)$ than those detected in specimens from the Mediterranean Sea (0.970 and $1.049 \mathrm{mg} \mathrm{kg}^{-1}$, respectively) (Damiano et al., 2011; Papetti and Rossi, 2009a). Thus, in general lead levels in our study were almost twelve times lower than mean lead levels in different mediterranean swordfish (e.g. Damiano et al., 2011). But our results are consistent with other studies conducted in the Mediterranean reported by Storelli et al., 2005, and by Kojadinovic et al., 2007 around the Reunion Island $\left(0.050\right.$ and $0.030 \mathrm{mg} \mathrm{kg}^{-1}$, respectively).

In the same way, the range of cadmium in this study is quite different $\left(0.033 \mathrm{mg} \mathrm{kg}^{-1}\right)$ from other values reported in the literature in the Mediterrenean Sea (e.g. respectively 0.158 and $0.005 \mathrm{mg} \mathrm{kg}^{-1}$, Storelli et al., 2005, Damiano et al., 2011). Thus, cadmium levels in our study were almost seven times higher than mean cadmium levels in other mediterranean swordfish (e.g. Damiano et al., 2011). However, cadmium levels observed are similar to other studies worldwide (e.g. $0.059 \mathrm{mg} \mathrm{kg}^{-1}$, Bodin et al., 2016).

Mean values of copper found in swordfish $\left(0.349 \mathrm{mg} \mathrm{kg}^{-1}\right)$ were similar to concentrations recorded in the muscle from Indian Ocean, which reached a mean of $0.342 \mathrm{mg} \mathrm{kg}^{-1}$ (Bodin et al., 2016). But these results were slightly higher than those observed in swordfish in the Indian Ocean and Atlantic Ocean (both $0.200 \mathrm{mg} \mathrm{kg}^{-1}$, Kojadinovic et al., 2007; Olmedo et al., 2013). In comparison with data reported by other authors, mean levels of iron $\left(4.808 \mathrm{mg} \mathrm{kg}^{-} 1\right)$ were similar to those reported by Kojadinovic et al., 2007 and Bodin et al., 2016 in the same species (5.90 and $4.124 \mathrm{mg} \mathrm{kg}^{-} 1$, respectively). The detected chrome and selenium levels ( 0.043 and $0.552 \mathrm{mg} \mathrm{kg}^{-1}$, respectively) were in good agreement with levels in sworfish in others studies $(0.044$ and $0.763 \mathrm{mg} \mathrm{kg}^{-1}$ respectively; Bodin et al., 2016). Our data $\left(0.072 \mathrm{mg} \mathrm{kg}^{-1}\right)$ were in accordance with manganese concentrations measured in fish from the Indian Ocean $\left(0.060 \mathrm{mg} \mathrm{kg}^{-1}\right.$, Kojadinovic et al., 2007), while lower values ranging from 0.013 to $0.036 \mathrm{mg} \mathrm{kg}^{-1}$ were reported in swordfish from Atlantic Ocean and Indian Ocean (Olmedo et al., 2013; Bodin et al., 2016). Zinc values in this study were high (from $30.275 \mathrm{mg} \mathrm{kg}^{-1}$ ), exceeding by far those reported in the Atlantic Ocean and the Indian Ocean $\left(5.637 \mathrm{and} 7.480 \mathrm{mg} \mathrm{kg}^{-1}\right.$ respectively (Olmedo et al., 2013; Bodin et al., 2016). But these values were comparable with those reported by Kojadinovic et al. (2007) $\left(22.9 \mathrm{mg} \mathrm{kg}^{-1}\right)$. The observed variability of TE levels in the swordfish might be a result of ecological needs, metabolism, and feeding patterns (Yilmaz, 2003).

The present work is the first study to examine a large range of trace elements (18) in swordfish. As far as we know, it is the first time that these $\mathrm{TE}(\mathrm{Ag}, \mathrm{Al}, \mathrm{Be}, \mathrm{Bi}, \mathrm{Co}, \mathrm{Mo}, \mathrm{Sb}, \mathrm{Sn}, \mathrm{V})$ were measured in this species. This study completes the database and brings new knowledge concerning levels of trace elements in $X$. gladius.

The relationship between the fish weight and the TE levels in the muscles was investigated. There was a significantly positive correlation between the weight and the concentrations of three TE $(\mathrm{Pb}: \mathrm{r}=0.35$, $\mathrm{p}<0.05 ; \mathrm{V}: \mathrm{r}=0.35, \mathrm{p}<0.05 ; \mathrm{Zn}: \mathrm{r}=0.60, \mathrm{p}<0.001)$ for $X$. gladius. In addition to the high intake of contaminants due to the high metabolic rates of the large predators, these results reflect the biomagnification process as the contaminants move up the food chain (Damiano et al., 2011). This process occurs because consumers feeding at higher trophic levels eat larger preys with higher body burdens that smaller ones (Bodin et al., 2016). Larger individuals have shown higher TE concentrations, as was previously reported in studies in certain fish species including swordfish (Mendez et al., 2001; Storelli and Marcotrigiano, 2001).

Various degrees of correlations were found between the elements. These accumulation relationships between TE could have negative correlations where metals compete, or positive correlations where TE accumulate together and influence one another (Renieri et al., 2014). For example, a significant positive correlation ( $\mathrm{p}<0.001$ ) between $\mathrm{Zn}$ and $\mathrm{Cu}, \mathrm{Pb}$ and $\mathrm{Bi}$, Mo and $\mathrm{Co}$ or $\mathrm{Fe}$ and $\mathrm{Cr}$ concentration were found. $\mathrm{A}$ significant negative correlation ( $\mathrm{p}<0.05$ ) between $\mathrm{Ag}$ and $\mathrm{Sn}, \mathrm{Cr}$ and Be, has been found.

Associations between these elements may reflect the biochemical regulation of element concentration or a requirement of elements (such as $\mathrm{Zn}$ and $\mathrm{Cu}$ ) for the synthesis of detoxifying proteins enzymes (e.g., glutathione and dismutases) as a feedback mechanism for an increase in toxic elements (Chang et al., 1998; Joyeux et al., 2004). These results can also show that some elements have similar sources (e.g. feeding) (Yllmaz et al., 2007). Thus, the correlations of TE (positive or negative) in fish tissues observed may be related to the elemental regulation which is affected by metabolic activity, environmental conditions and physiological needs (Kojadinovic et al., 2007).

Despite the human fishing pressure on swordfish, there is a great lack of knowledge on trace element levels in these fish (Kojadinovic et al., 2007). The findings of this study amplify the scarce database on contaminants available, especially new data on "emerging elements", for this species from the Mediterranean Sea. Data on TE in swordfish have served to warn of the possible risk related to the consumption, although the data considered in the study indicate that there is no risk for a controlled ingestion.

Due to the increasing environmental pressure on the Mediterranean Sea, a regular monitoring of TE levels in marine organisms is necessary to prevent any further environmental deterioration and to assess the human exposure. These data on contaminant levels in fish from particular regions of the world could allow people to make informed decisions about which fish to eat to reduce their risk from the contaminants (Tepe, 2009).

\section{Acknowledgements}

This study is part of the STARECAPMED (Station of Reference and Research on Change of local and global Anthropogenic Pressures on Mediterranean Ecosystems Drifts) project funded by the Territorial Collectivity of Corsica and by The French Water Agency (PACA-Corsica) Convention No. 2017-05-11. This research was also funded by the "Office de l'Environnement de la Corse (OEC), the STARESO and the "Università di Corsica Pasquale Paoli" (UCPP). Special thanks are extended to the "Comité Régional des Pêches Maritimes et Élevages Marins" (CRPMEM) and the fishermen of the Island of Corsica for their collaboration. This publication has the MARE publication number MARE356.

\section{References}

Abascal, F.J., Mejuto, J., Quintans, M., Ramos-Cartelle, A., 2010. Horizontal and vertical movements of swordfish in the Southeast Pacific. ICES J. Mar. Sci. J. Cons. 67, 466-474.

Aliçli, T.Z., Oray, I.K., 2001. Age and growth of swordfish (Xiphias gladius L., 1758) in the eastern Mediterranean Sea. Col. Vol. Sci. Pap. ICCAT 52, 698-707.

Araújo, C.V.M., Cedeño-Macias, L.A., 2016. Heavy metals in yellowfin tuna (Thunnus albacares) and common dolphinfish (Coryphaena hippurus) landed on the Ecuadorian coast. Sci. Total Environ. 541, 149-154. http://dx.doi.org/10.1016/j.scitotenv.2015. 09.090.

Baeyens, W., Leermakers, M., Gieter, M.D., Nguyen, H.L., Parmentier, K., Panutrakul, S., Elskens, M., 2005. Overview of trace metal contamination in the Scheldt estuary and effect of regulatory measures. Hydrobiologia 540, 141-154.

Bakan, G., Büyükgüngör, H., 2000. The Black Sea. Seas Millenn. Environ. Eval. 41, 24-43. http://dx.doi.org/10.1016/S0025-326X(00)00100-4.

Bat, L., Sezgin, M., Üstün, F., Sahin, F., 2012. Heavy metal concentrations in ten species of fishes caught in Sinop coastal waters of the Black Sea, Turkey. Turk. J. Fish. Aquat. Sci. 12, 371-376.

Bodin, N., Lesperance, D., Albert, R., Hollanda, S., Degroote, M., Churlaud, C., Bustamante, P., 2016. A Preliminary Study of Trace Elements in Oceanic Pelagic Communities in the Western-central Indian Ocean.

Castro-González, M.I., Méndez-Armenta, M., 2008. Heavy metals: implications associated to fish consumption. Environ. Toxicol. Pharmacol. 26, 263-271.

Chamannejadian, A., Sayyad, G., Moezzi, A., Jahangiri, A., 2013. Evaluation of estimated daily intake (EDI) of cadmium and lead for rice (Oryza sativa L.) in calcareous soils. 
Iran. J. Environ. Health Sci. Eng. 10, 28.

Chang, S., Zdanowicz, V.S., Murchelano, R.A., 1998. Associations between liver lesions in winter flounder (Pleuronectes americanus) and sediment chemical contaminants from north-east United States estuaries. ICES J. Mar. Sci. J. Cons. 55, 954-969.

Collette, B., Acero, A., Amorim, A.F., Bizsel, K., Boustany, A., Canales Ramirez, C., Cardenas, G., Carpenter, K.E., de Oliveira Jr., Leite, Di Natale, A., Die, D., Fox, W., Fredou, F.L., Graves, J., Guzman-Mora, A., Viera Hazin, F.H., Hinton, M., Juan Jorda, M., Minte Vera, C., Miyabe, N., Montano Cruz, R., Masuti, E., Nelson, R., Oxenford, H., Restrepo, V., Salas, E., Schaefer, K., Schratwieser, J., Serra, R., Sun, C., Teixeira Lessa, R.P., Pires Ferreira Travassos, P.E., Uozumi, Y., Yanez, E., 2016. Xiphias gladius (Broadbill, Broadbill Swordfish, Swordfish). ([WWW Document]. URL). http://www. iucnredlist.org/details/summary/23148/0 (accessed 1.31.17).

Copat, C., Arena, G., Fiore, M., Ledda, C., Fallico, R., Sciacca, S., Ferrante, M., 2013. Heavy metals concentrations in fish and shellfish from eastern Mediterranean Sea: consumption advisories. Food Chem. Toxicol. 53, 33-37.

Currie, L.A., 1999. Nomenclature in evaluation of analytical methods including detection and quantification capabilities1: (IUPAC Recommendations 1995). Anal. Chim. Acta 391, 105-126. http://dx.doi.org/10.1016/S0003-2670(99)00104-X.

Dadar, M., Adel, M., Ferrante, M., Nasrollahzadeh Saravi, H., Copat, C., Oliveri Conti, G., 2016. Potential risk assessment of trace metals accumulation in food, water and edible tissue of rainbow trout (Oncorhynchus mykiss) farmed in Haraz River, northern Iran. Toxin Rev. 35, 141-146.

Damiano, S., Papetti, P., Menesatti, P., 2011. Accumulation of heavy metals to assess the health status of swordfish in a comparative analysis of Mediterranean and Atlantic areas. Mar. Pollut. Bull. 62, 1920-1925. http://dx.doi.org/10.1016/j.marpolbul. 2011.04.028.

Demirak, A., Yilmaz, F., Tuna, A.L., Ozdemir, N., 2006. Heavy metals in water, sediment and tissues of Leuciscus cephalus from a stream in southwestern Turkey. Chemosphere 63, 1451-1458.

Di Bella, G., Potortì, A.G., Lo Turco, V., Bua, D., Licata, P., Cicero, N., Dugo, G., 2015. Trace elements in Thunnus thynnus from Mediterranean Sea and benefit-risk assessment for consumers. Food Addit. Contam. Part B 8, 175-181. http://dx.doi. org/10.1080/19393210.2015.1030347.

E.U, 2008. Commission Regulation (EC) No. 629/2008 of 2 July 2008 amending Regulation (EC) No. 1881/2006 setting maximum levels for certain contaminants in foodstuffs. Off. J. Eur. Union L 173, 6-9.

El-Moselhy, K.M., Othman, A.I., Abd El-Azem, H., El-Metwally, M.E.A., 2014. Bioaccumulation of heavy metals in some tissues of fish in the Red Sea, Egypt. Egypt. J. Basic Appl. Sci. 1, 97-105. http://dx.doi.org/10.1016/j.ejbas.2014.06.001.

Erkan, N., Özden, Ö., Ulusoy, Ș., 2009. Levels of trace elements in commercially important fish, crustaceans and mollusks from Istanbul fish market. Fresenius Environ. Bull. 18, 1307-1311.

FAO, 2016. La situation mondiale des pêches et de l'aquaculture 2016. In: Contribuer à la sécurité alimentaire et à la nutrition de tous, (Rome).

Guven, K., Özbay, C., Ünlu, E., Satar, A., 1999. Acute lethal toxicity and accumulation of copper in Gammarus pulex (L.) (Amphipoda). Turk. J. Biol. 23, 513-522.

Hernández-García, V., 1995. The diet of the swordfish Xiphias gladius Linnaeus, 1758, in the central east Atlantic, with emphasis on the role of cephalopods. Fish. Bull. 93, 403-411.

Joyeux, J.-C., Campanha Filho, E.A., Jesus, H.C. de, 2004. Trace metal contamination in estuarine fishes from Vitória Bay, ES, Brazil. Braz. Arch. Biol. Technol. 47, 765-774.

Kalay, M., Ay, Ö., Canli, M., 1999. Heavy metal concentrations in fish tissues from the Northeast Mediterranean Sea. Bull. Environ. Contam. Toxicol. 63, 673-681.

Kojadinovic, J., Potier, M., Le Corre, M., Cosson, R.P., Bustamante, P., 2007. Bioaccumulation of trace elements in pelagic fish from the Western Indian Ocean. Environ. Pollut. 146, 548-566.

Kotoulas, G., Magoulas, A., Tsimenides, N., Zouros, E., 1995. Marked mitochondrial DNA differences between Mediterranean and Atlantic populations of the swordfish, Xiphias gladius. Mol. Ecol. 4, 473-482.

Macías, D., Hattour, A., De la Serna, J.M., Gómez-Vives, M.J., Godoy, D., 2005. Reproductive characteristics of swordfish (Xiphias gladius) caught in the southwestern Mediterranean during 2003. Col. Vol. Sci. Pap. ICCAT 58, 454-469.

Malak, D.A., 2011. Overview of the Conservation Status of the Marine Fishes of the Mediterranean Sea. IUCN.

Mansour, S.A., Sidky, M.M., 2002. Ecotoxicological studies. 3. Heavy metals contaminating water and fish from Fayoum Governorate, Egypt. Food Chem. 78, $15-22$.

Medeiros, R.J., dos Santos, L.M.G., Freire, A.S., Santelli, R.E., Braga, A.M.C.B., Krauss, T.M., Jacob, S.do.C., 2012. Determination of inorganic trace elements in edible marine fish from Rio de Janeiro State, Brazil. Food Control 23, 535-541. http://dx. doi.org/10.1016/j.foodcont.2011.08.027.

Mendez, E., Giudice, H., Pereira, A., Inocente, G., Medina, D., 2001. Total mercury content-fish weight relationship in swordfish (Xiphias gladius) caught in the southwest Atlantic Ocean. J. Food Compos. Anal. 14, 453-460. http://dx.doi.org/10 1006/jfca.2001.1005.

Mendil, D., Demirci, Z., Tuzen, M., Soylak, M., 2010. Seasonal investigation of trace element contents in commercially valuable fish species from the Black sea, Turkey. Food Chem. Toxicol. 48, 865-870. http://dx.doi.org/10.1016/j.fct.2009.12.023.

Muñoz-Olivas, R., Cámara, C., 2001. Speciation related to human health. Trace Elem. Speciat. Environ. Food Health 331-353.

Nakamura, I., 1985. An annotated and illustrated catalogue of marine sailfishes, spearfishes and swordfishes known to date. In: FAO Species Catalogue. Billfishes of the World. FAO Fish Synop 125, vol. 5.

Neves dos Santos, M., Saber, S., Macias, D., Ortiz de Urbina, J., Kell, L., Tserpes, G., Die, D., Coelho, R., 2016. Report of the 2016 Mediterranean Swordwish Stock Assessment Meeting.

Olmedo, P., Hernández, A.F., Pla, A., Femia, P., Navas-Acien, A., Gil, F., 2013. Determination of essential elements (copper, manganese, selenium and zinc) in fish and shellfish samples. Risk and nutritional assessment and mercury-selenium balance. Food Chem. Toxicol. 62, 299-307.

Olsson, P.-E., Kling, P., Hogstrand, C., 1998. Mechanisms of heavy metal accumulation and toxicity in fish. In: Metal Metabolism in Aquatic Environments. Springer, pp. $321-350$.

Onsanit, S., Chen, M., Ke, C., Wang, W.-X., 2012. Mercury and stable isotope signatures in caged marine fish and fish feeds. J. Hazard. Mater. 203, 13-21.

Papetti, P., Rossi, G., 2009a. Heavy metals in the fishery products of low Lazio and the use of metallothionein as a biomarker of contamination. Environ. Monit. Assess. 159, 589-598.

Papetti, P., Rossi, G., 2009b. Heavy metals in the fishery products of low Lazio and the use of metallothionein as a biomarker of contamination. Environ. Monit. Assess. 159, 589-598.

Pastor, A., Hernandez, F., Peris, M.A., Beltran, J., Sancho, J.V., Castillo, M.T., 1994. Levels of heavy metals in some marine organisms from the western Mediterranean area (Spain). Mar. Pollut. Bull. 28, 50-53.

Renieri, E.A., Alegakis, A.K., Kiriakakis, M., Vinceti, M., Ozcagli, E., Wilks, M.F., Tsatsakis, A.M., 2014. Cd, $\mathrm{Pb}$ and $\mathrm{Hg}$ biomonitoring in fish of the mediterranean region and risk estimations on fish consumption. Toxics 2, 417-442.

Storelli, M.M., Marcotrigiano, G.O., 2001. Total mercury levels in muscle tissue of swordfish (Xiphias gladius) and bluefin tuna (Thunnus thynnus) from the Mediterranean Sea (Italy). J. Food Prot. 64, 1058-1061.

Storelli, M.M., Giacominelli-Stuffler, R., Storelli, A., Marcotrigiano, G.O., 2005 Accumulation of mercury, cadmium, lead and arsenic in swordfish and bluefin tuna from the Mediterranean Sea: a comparative study. Mar. Pollut. Bull. 50, 1004-1007. http://dx.doi.org/10.1016/j.marpolbul.2005.06.041.

Storelli, M.M., Barone, G., Piscitelli, G., Marcotrigiano, G.O., 2007. Mercury in fish: concentration vs. fish size and estimates of mercury intake. Food Addit. Contam. 24, 1353-1357.

Szefer, P., Domagała-Wieloszewska, M., Warzocha, J., Garbacik-Wesołowska, A., Ciesielski, T., 2003. Distribution and relationships of mercury, lead, cadmium, copper and zinc in perch (Perca fluviatilis) from the Pomeranian Bay and Szczecin Lagoon, southern Baltic. Food Chem. 81, 73-83.

Tepe, Y., 2009. Metal concentrations in eight fish species from Aegean and Mediterranean seas. Environ. Monit. Assess. 159, 501-509.

Türkmen, M., Türkmen, A., Tepe, Y., Ateş, A., Gökkuş, K., 2008. Determination of metal contaminations in sea foods from Marmara, Aegean and Mediterranean seas: twelve fish species. Food Chem. 108, 794-800.

Tuzen, M., Soylak, M., 2007. Determination of trace metals in canned fish marketed in Turkey. Food Chem. 101, 1378-1382.

Uluozlu, O.D., Tuzen, M., Mendil, D., Soylak, M., 2007. Trace metal content in nine species of fish from the Black and Aegean Seas, Turkey. Food Chem. 104, 835-840. http://dx.doi.org/10.1016/j.foodchem.2007.01.003.

Vlieg, P., Murray, T., Body, D.R., 1993. Nutritional data on six oceanic pelagic fish species from New Zealand waters. J. Food Compos. Anal. 6, 45-54.

WHO, 2014. Summary Report of the Seventy-Third Meeting of JECFA. Joint FAO/WHO Expert Committee on Food Additives, Geneva, Switzerland.

Yildirim, Y., Gonulalan, Z., Narin, I., Soylak, M., 2009. Evaluation of trace heavy metal levels of some fish species sold at retail in Kayseri, Turkey. Environ. Monit. Assess. $149,223-228$.

Yilmaz, A.B., 2003. Levels of heavy metals (Fe, Cu, Ni, Cr, Pb, and $\mathrm{Zn}$ ) in tissue of Mugi cephalus and Trachurus mediterraneus from Iskenderun Bay, Turkey. Environ. Res. 92, $277-281$.

Yilmaz, F., Özdemir, N., Demirak, A., Tuna, A.L., 2007. Heavy metal levels in two fish species Leuciscus cephalus and Lepomis gibbosus. Food Chem. 100, 830-835. 